\title{
Predicting Critical Thinking Ability of Sultan Qaboos University Students
}

\author{
Hussain Ali Alkharusi \\ Sultan Qaboos University, Oman, hussein5@squ.edu.om
}

\section{Humaira Al Sulaimani}

Sultan Qaboos University, Oman, alsuleimanih@gmail.com

\section{Otherine Neisler}

Sultan Qaboos University, Oman, oneisler@gmail.com

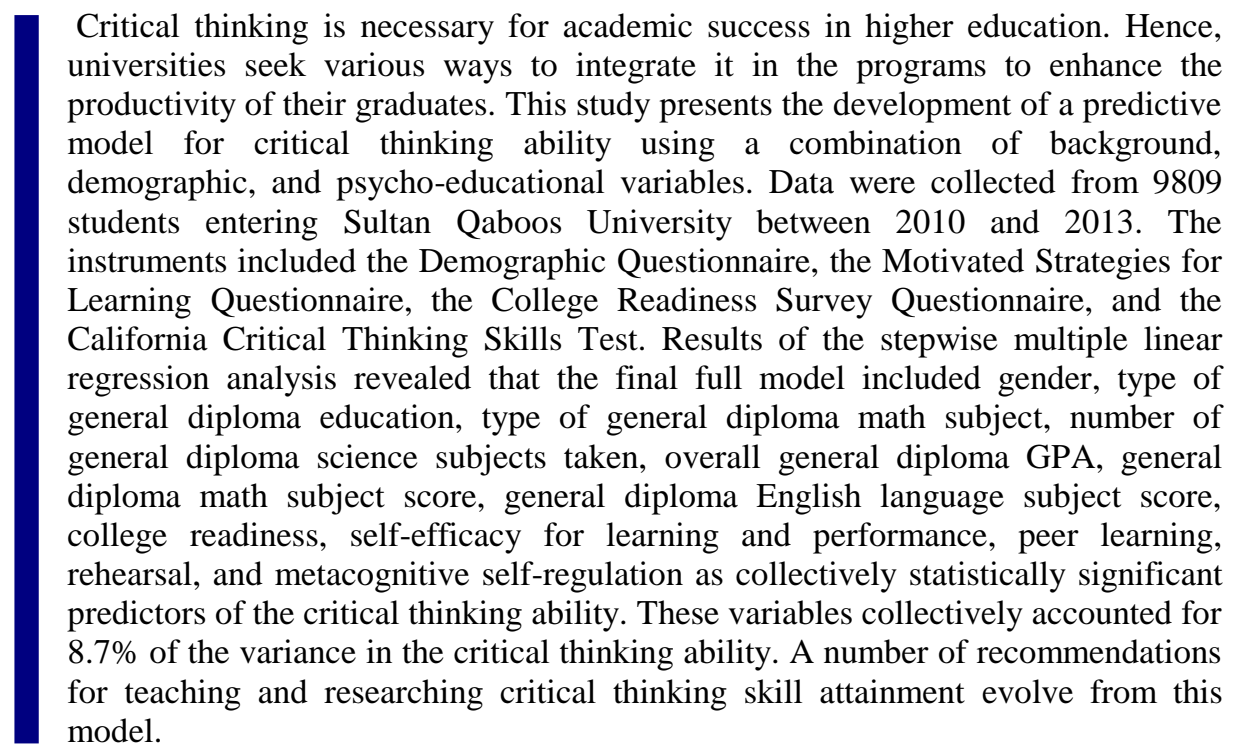

Keywords: predictive validity, academic achievement, university GPA, motivation, learning strategies, critical thinking

\section{INTRODUCTION}

The nature of pedagogy in higher education requires students to be able to organize knowledge, develop and evaluate arguments, and come up with inferences. As such, critical thinking is necessary for academic success in higher education (Magno, 2010;

Citation: Alkharusi, H. A., Sulaimani, H. A., \& Neisler, O. (2019). Predicting Critical Thinking Ability of Sultan Qaboos University Students. International Journal of Instruction, 12(2), 491-504. https://doi.org/10.29333/iji.2019.12231a 
Neisler, 1999; 2000; Paul \& Elder, 2006). However, students graduate from secondary school with skills below the expected levels for entrance into higher education. Specifically, there has been a concern about the adequacy of preparation of secondary school graduates in skills related to mathematics, reading comprehension, and writing (Gonzalez, Karoly, Constant, Salem, \& Gold, 2008). When considering Sultanate of Oman, each year between 40,000-50,000 students graduate from secondary school with only half of them being accepted into higher education institutions (Ministry of Education \& the World Bank, 2012; Times News Service, 2014.) Of those, approximately 3,000 students are accepted at Sultan Qaboos University (SQU). Over half of the newly admitted students at SQU failed either the math or the technology placement examinations and fewer than $10 \%$ passed the examination for university readiness in English. It has been documented that students with better critical thinking skills tended to have higher levels of academic achievement (Ip, Lee, Lee, Chau, Wootton, \& Chang, 2000; Phan, 2008; Hohmann \& Grillo, 2014). Therefore, it is important to identify factors that can facilitate the development of critical thinking skills for university students.

There are many conceptualizations of critical thinking. For example, Wade and Tavris (1987) state that critical thinking refers to "the ability and willingness to assess claims and make objective judgments on the basis of well-supported reason" (p. 308-309). Beyer (1984) described critical thinking as a combination of skills needed to analyze and evaluate information. Mayer and Goodchild (1990) defined critical thinking as an active and systematic process to understand and evaluate arguments. Despite differences among researchers in defining critical thinking, they tend to agree that critical thinking involves two components: skills or abilities and dispositions. The abilities which are recognized as related to the critical thinking include analyzing arguments, claims, or evidence; making inferences using inductive or deductive reasoning; making judgments or evaluations; making decisions or solving problems; asking and answering questions for clarification; defining terms; identifying assumptions; making interpretations and explanations; reasoning verbally; making predictions; seeing both sides of an issue (Lai, 2011). Also, critical thinking includes the skill of argumentation (Davies, 2013). The dispositions agreed to be relevant to the critical thinking include open-mindedness; fairmindedness; the propensity to seek reason; inquisitiveness; the desire to be wellinformed; flexibility; and respect for, and willingness to entertain, others' viewpoints (Lai, 2011).

Based on these conceptualizations of critical thinking, several tests have been developed for measuring critical thinking such as the Watson-Glaser Critical Thinking Appraisal (Watson \& Glaser, 1980); the Test on Appraising Observations (Norris \& King, 1984); the Ennis-Weir Critical Thinking Essay Test (Ennis \& Weir, 1985); the California Critical Thinking Skills Test (Facione, 1990), and the Cornell Critical Thinking Test Level X (Ennis \& Millman, 1985). The California Critical Thinking Skills Test (CCTST) has been preferred compared to the other tests for the quality of its questions (Ingle, 2007). A number of studies reported validity of the CCTST for samples of students from United States (Facione, 1990), Iran (Khalili \& Zadeh, 2003), and United Kindom (O'Hare \& McGuinness, 2015). 
The current study accepted that critical thinking is a conventional quantitative measure that can be calculated through the use of The California Critical Thinking Skills Test (CCTST). The CCTST was developed by Facione and Facione in the 1990s (Facinoe, 2011). It is based on the American Philosophical Association Delhi consensus definition of critical thinking as the process of purposeful, self-regulatory judgement encompassing five core skills which are: interpretation, analysis, evaluation, inferences, explanation, and self-regulation. Interpretation involves categorization, decoding sentences, and clarifying meaning. Analysis includes examining ideas and, identifying and analyzing arguments. Evaluation refers to the assessment of the credibility of claims and arguments. Making inferences involves drawing conclusions after questioning evidence and speculating about alternatives and includes both inductive and deductive reasoning. Explanation includes articulating results, justifying procedures, and presenting arguments. Self-regulation involves self-examination and self-correction (Facione, 2013).

A limited number of studies have investigated correlates of critical thinking. For example, Ingle (2007) examined predictors of critical thinking ability among 296 community college and university students. Critical thinking was measured using the CCTST and the Ennis-Weir Critical Thinking Essay. Predictors included meta-cognitive self-regulation, elaboration, application, organization, peer learning, help seeking, type of collegiate institution, age, and gender of participant; controlling for intrinsic and extrinsic goal orientations. For each measure of the criterion variable, results of hierarchical linear regression analyses showed that meta-cognitive self-regulation and elaboration were the most robust predictors of critical thinking ability. Ingle called for more research on predictors of critical thinking ability among university students.

Using the California Critical Thinking Disposition Inventory and Heppner and Petersen's (1982) Problem Solving Inventory, Tümkaya, Aybek, \& Aldağ (2009) examined the relationship between university students' critical thinking disposition and problem-solving skills as well as determining the differences based on gender, grade level, and field of study. The sample contained 353 volunteer male and female students from different university departments. Results revealed significant positive correlation between participants' level of critical thinking disposition and perceived problemsolving skills, meaning that a better disposition towards critical thinking was associated with greater problem-solving skills. Also, there were no significant gender differences on problem solving and critical thinking disposition. Additionally, social science students had higher levels of critical thinking dispositions compared to science students. Further, grade level was significantly related to both problems solving and critical thinking dispositions.

Using the Watson-Glaser Critical Thinking Appraisal as the measure of critical thinking, Magno (2010) investigated the effect of meta-cognition on critical thinking skills among 240 college students in the Philippines. Results of structural equation modeling showed a statistically significant relationship between meta-cognition and critical thinking. Magno asserted the importance of employing pedagogical strategies based on metacognitive skills in order to help facilitate the development of students' critical thinking skills. 
Mahapoonyanont (2012) examined factors related to critical thinking skills. The study was implemented in two phases. In phase one, the researcher conducted a meta-analysis of research studies related to the factors affecting critical thinking abilities of high school students from 1988 to 2008, while in phase two, the empirical data of students from basic education institutions was used for the development and verification of a causal model of factors that affect critical thinking. The results showed that the factors related to critical thinking skills were teaching methods, student reading ability, and child rearing. Results also revealed that reading ability was the factor most related to critical thinking skills followed by teacher roles in arranging student-centered learning environments. Moreover, a value of 0.64 was the predictive correlation of critical thinking ability, meaning that the causal factors of the model could explain variance of critical thinking skills at $64 \%$.

Using a self-report of measure of critical thinking, which is a dimension of the Motivated Strategies for Learning Questionnaire, Uzuntiryaki-Kondakçi and ÇapaAydin (2013) examined the extent to which meta-cognitive self-regulation and chemistry self-efficacy predicted critical thinking of 365 university students in Turkey. Chemistry self-efficacy refers to students' beliefs about their capabilities to do chemistry tasks successfully. Results of structural equation modeling showed that meta-cognitive selfregulation had statistically significant direct and indirect relationships with critical thinking through self-efficacy.

Using the California Critical Thinking Disposition Inventory (CCTDI) as a measure of the critical thinking, Arslan, Gulveren and Aydin (2014) investigated the critical thinking tendencies of higher education students in Turkey. A sample of 1,293 freshman and senior university students from different colleges were randomly selected to determine their critical thinking levels depending on demographic characteristics. The results illustrated that female students have more critical thinking abilities than male students. Also, students from Economics and Administrative Sciences had more critical thinking abilities than their counterparts from Education and Engineering.

Karagol and Bekmezci (2015) conducted a study with 377 teacher candidates to investigate whether critical thinking dispositions and academic achievement scores differ according to gender, type of high school attended, specialization, and parents' income level. The findings revealed that gender, type of high school, and income level of parents did not have significant effects on critical thinking dispositions. Yet, significant relationships were found between critical thinking dispositions and academic achievements of teacher candidates.

In an Indonesian University, Indah and Kusuma (2016) analyzed evaluating essays written by 130 English major students and questionnaire data to assess the factors affecting the level of critical thinking. The analysis of students' written essays revealed a positive relationship between critical thinking and language mastery. Also, the findings revealed weak correlations between critical thinking and the following factors: students' cultural background, family background, family education, learning strategies, and reading habits. 
Overall, it seems that there is limited research on predictors of critical thinking among university students. Besides the differences in the operational definition of critical thinking, factors considered in the previous studies were limited in scope. The present study attempts to address the gap in the literature by considering both background and demographic variables as well as psycho-educational variables. Also, the criterion variable is measured using the CCTST, which has been judged as a superior instrument for measuring critical thinking of university students (Ingle, 2007). The importance of the current study stems from the notion that the development of critical thinking skills should be part of the educational curriculum at Sultan Qaboos University (Sultan Qaboos University, 2017). As such, identifying predictors of critical thinking among incoming university students should provide educators the ground for designing appropriate programs that would promote the development of critical thinking. Replication of the study is necessary to test the applicability of the findings in other similar university settings.

\section{Research Question}

This study was guided by the following research question: Which combination of background, demographic, and psycho-educational variables contribute most to the variance explained in the critical thinking ability of Sultan Qaboos University students?

\section{METHOD}

\section{Sample}

Data were collected for 9809 Omani students selected conveniently from the population of students entering Sultan Qaboos University (SQU) between 2010 and 2013. There were $4700(47.9 \%)$ males and $5109(52.1 \%)$ females. About $45.7 \%$ (4483) were graduates of the basic education schools and $54.3 \%$ (5326) were graduates of the nonbasic education schools. The term basic education refers to an educational system established in Oman in 1998. It lasts for ten years of study. At its end, the student moves to the post-basic education, which covers four semesters in two years. The non-basic education refers to the traditional educational system established in Oman in 1970. It consists of six years of elementary, three years of preparatory, and three years of secondary levels of study. Students in the basic education system study English language subject starting from the first grade whereas students in the non-basic education system study English language subject starting from the fourth grade.

About two-third of the students (6256) were admitted in science colleges and 3553 students were admitted in humanities colleges at SQU. The majority of the students (72.2\%) studied pure mathematics in the general education diploma whereas (27.8\%) studied applied mathematics. With respect to the number of science subjects taken in the general education diploma, $13.6 \%$ (1330) did not take any science subject, $1.4 \%$ (138) took one science subject, 5\% (487) took two science subjects, and 80.1\% (7854) took three science subjects.

\section{Instrumentation}

Three instruments were used in the study: The California Critical Thinking Skills Test (CCTST), the Motivated Strategies for Learning Questionnaire (MSLQ), and the 
College Readiness Survey Questionnaire (UR). The background data of the sample were obtained from the database of the Sultan Qaboos University Deanship of Admissions and Registration. In this study, validity of the items of the instruments was verified by asking a group of seven faculty members from College of Education and Language Center at Sultan Qaboos University to judge the clarity, relevance, and appropriateness of the items for the measurement purposes of the current investigation. According to the judges, no major changes were needed for the items. Following is a description of the instruments.

\section{The Motivated Strategies for Learning Questionnaire (MSLQ)}

This instrument was developed by Pintrich, Smith, Garcia, Mckeachie (1993) to measure motivational orientations and learning resources and strategies of college students. The Arabic version of the MSLQ was used in this study, which was validated for SQU students (Alkharusi, Neisler, Al-Barwani, Clayton, Al-Sulaimani, Khan, AlYahmadi, \& Al-Kalbani, 2012). It consisted of 65 items divided into two sections: a motivation section and a learning resources and strategies section. The motivation section consisted of 20 items assessing students' intrinsic goal orientation (4 items, $\alpha=$ .74 ), extrinsic goal orientation ( 4 items, $\alpha=.62$ ), control beliefs about learning ( 4 items, $\alpha=.68$ ), and self-efficacy ( 8 items, $\alpha=.93$ ). The learning resources and strategies section consisted of 45 items assessing students' use of rehearsal (4 items, $\alpha=.69$ ), elaboration (6 items, $\alpha=.75$ ), organization ( 4 items, $\alpha=.64$ ), metacognitive selfregulation (12 items, $\alpha=.79$ ), time and study environment ( 8 items, $\alpha=.76$ ), effort regulation ( 4 items, $\alpha=.69$ ), peer learning ( 3 items, $\alpha=.76$ ), and help seeking ( 4 items, $\alpha=.52$ ). Responses were obtained on a 7-point Likert scale ranging from 1 (not at all true of me) to 7 (very true of me). Scoring of the negative items was reversed so that higher scores reflected a more positive motivational orientation and use of learning strategies. An average rating score was constructed for each component of the MSLQ.

\section{The California Critical Thinking Skills Test (CCTST)}

The CCTST was used to collect data on critical thinking ability of the participants. It is an intellectually challenging standardized 34 multiple choice-items instrument administered over a 45 minute period to test cognitive skills. The items are based on common topics intended to be of short, discipline-neutral content; problem statements; and scenarios grouped into six subscales including analysis, evaluation, inference, explanation, interpretation, and self-regulation (Facione, 2000). Critical thinking ability was operationally defined as a total score summed across all items of the CCTST. The internal reliability coefficient for CCTST scores was .81 as computed using Kuder Richardson (KR-20) method.

\section{The College Readiness Survey Questionnaire (UR)}

This questionnaire mainly consisted of items adapted from the questionnaire developed by the TRIO Student Support Services program which is funded by the United States Department of Education. The original college readiness survey consisted of 53 items measured on a 7-point Likert-type scale. The UR measured students' readiness for college in terms of their perceptions about academic confidence, financing college, 
reasons for going to college, tackling college, teachers, career awareness, reading and writing, math and science, and social support. The items of this questionnaire were translated from English to Arabic by the faculty research team. This questionnaire was also modified by the research team with respect to some cultural issues and research aims. The reading and writing items included students' perceptions about their skills in Arabic and English because Arabic is the mother tongue of this population all of whom have also studied English as a foreign language. Additional items regarding students' perceptions about their computer skills were included in the questionnaire. The final version of the UR consisted of 67 items. An overall college readiness level was constructed by an average rating score across all items. The reliability coefficient was .76 as measured by Cronbach alpha.

\section{Procedures}

For each cohort between 2010 and 2013, permission to collect data from the students was requested and obtained from the University administration. The research team informed the students that a study was being conducted to identify predictors of critical thinking of university students. Then, the team requested the participation of the students. Emphasis was placed on the fact that information to be gathered would not influence their admission in the university in any way and that the study would potentially lead to improve learning in the university. Students who wished to participate in the study were given the CCTST, MSLQ, and the UR.

\section{Analysis}

Means and standard deviations were computed to describe the sample in terms of the variables considered in the study. A stepwise multiple linear regression analysis was conducted to identify the factors that most contribute to the variance explained in the critical thinking ability. Factors considered in the analysis were gender, type of school education, type of mathematics subject taken in the general education diploma, type of college, general education diploma average score, general education diploma mathematics subject score, general education diploma English language subject score, number of science subjects taken in the general education diploma, university readiness, motivational traits, and learning strategies. The dependent variable was the total critical thinking score obtained on the CCTST. Gender, type of school education, type of mathematics subject, and type of college were dummy coded as 0 for males and 1 for females; 0 for basic education and 1 for non-basic education; 0 for applied mathematics and 1 for pure mathematics; and 0 for science colleges and 1 for humanities colleges; respectively.

Prior to the analysis, an evaluation of the assumptions of normality, linearity, homoscedasticity as well as multicollinearity and singularity was performed on the data. Figure 1 and Figure 2 show a distribution of the residuals. The scatterplot of residuals against predicted dependent variable scores showed that the residuals were approximately distributed in a rectangular shape with a concentration of scores along the center. As such, as shown in Figure 1 and Figure 2, the assumptions of normality, linearity, and homoscedasticity were met. 


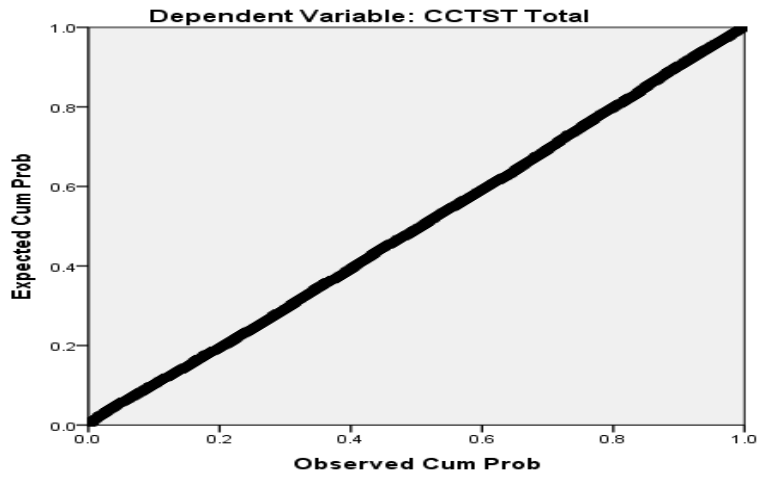

Figure 1

Normal P-P Plot of Regression Standardized Residuals

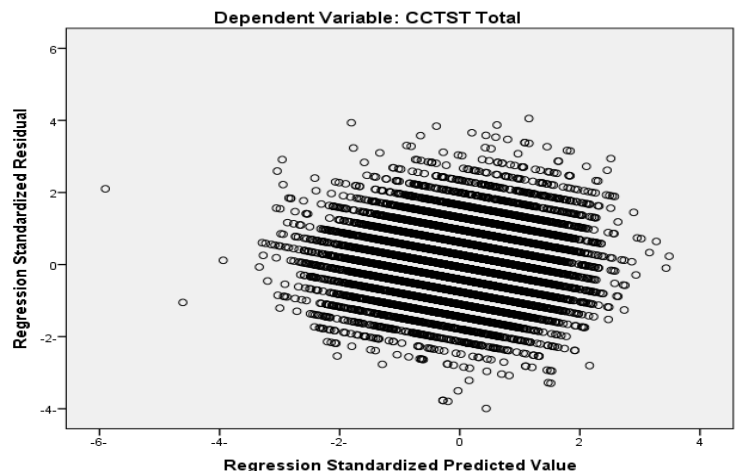

Figure 2

A Scatterplot of Regression Standardized Residuals

It was also found that the highest bivariate correlation among the independent variables did not exceed .65. In addition, the values of the tolerances ranged between .231 and 977. Also, the values of the variance inflation factor ranged between 1.024 and 4.335. According to Tabachnick and Fidell (2001), these results led to a conclusion that there was no concern about multicollinearity and singularity.

\section{FINDINGS}

Table 1 presents descriptive statistics of the variables considered in the analysis. A stepwise multiple linear regression analysis was conducted to identify which combination of variables contribute most to the variance explained in the critical thinking ability of the university students. The dependent variable was the total critical thinking score obtained on the CCTST. 
Table 1

Descriptive Statistics of the Variables Considered in the Analysis ( $\mathrm{N}=9809)$

\begin{tabular}{lll}
\hline Variable & $M$ & $S D$ \\
\hline Critical thinking & 11.20 & 3.04 \\
General education diploma average score & 88.86 & 5.69 \\
General education diploma mathematics subject score & 83.85 & 11.81 \\
General education diploma English language subject score & 82.82 & 9.54 \\
Number of science subjects taken in the general education diploma & 2.52 & 1.05 \\
University readiness & 4.50 & .42 \\
Intrinsic goal orientation & 5.60 & .99 \\
Extrinsic goal orientation & 6.12 & .95 \\
Control of learning beliefs & 5.53 & .93 \\
Self-efficacy for learning and performance & 5.89 & .87 \\
Rehearsal & 5.68 & 1.03 \\
Elaboration & 5.57 & 1.05 \\
Organization & 5.61 & 1.12 \\
Self-regulation & 5.43 & .80 \\
Time and study environment & 5.31 & .75 \\
Effort regulation & 5.06 & 1.08 \\
Peer learning & 4.64 & 1.28 \\
Help-seeking & 5.02 & 1.04 \\
\hline
\end{tabular}

In twelve steps, the full model included gender, type of school education, type of mathematics subject taken in the general education diploma, general education diploma average score, general education diploma mathematics subject score, general education diploma English language subject score, number of science subjects taken in the general education diploma, university readiness, self-efficacy for learning and performance, rehearsal, self-regulation, and peer learning as collectively statistically significant predictors of the critical thinking ability. Table 2 summarizes the regression model of the critical thinking ability. The model accounted for $8.7 \%$ (Adjusted $R^{2}=.086$ ) of the variance in the critical thinking ability, $F(12,9795)=78.20, p<.001$. The calculated effect size of the model was .095, which is considered close to the "medium" effect according to Cohen's (1988) classification of small (.02), medium (.15), and large (.35) effect sizes.

Table 2

Regression Analysis Summary for Predicting Critical Thinking Ability ( $\mathrm{N}=9809)$

\begin{tabular}{lllll}
\hline Variable & $B$ & $S E B$ & $\beta$ & $s r^{2}$ \\
\hline General education diploma English language subject score & 0.05 & .004 & $.16^{*}$ & .0160 \\
Type of mathematics subject taken in the general education & 0.87 & .09 & $.13^{*}$ & .0083 \\
Type of school education & -.47 & .06 & $-.08^{*}$ & .0062 \\
General education diploma mathematics subject score & 0.03 & .004 & $.13^{*}$ & .0048 \\
Gender & -.54 & 0.08 & $-.09^{*}$ & .0045 \\
University readiness & -.49 & .08 & $-.07^{*}$ & .0036 \\
Rehearsal & -0.14 & .04 & $-.05^{*}$ & .0012 \\
Self-efficacy for learning and performance & 0.14 & .04 & $.04^{*}$ & .0012 \\
Self-regulation & 0.17 & .05 & $.04^{*}$ & .0010 \\
General education diploma average score & 0.03 & .01 & $.06^{*}$ & .0008 \\
Peer learning & -0.08 & .03 & $-.03^{*}$ & .0008 \\
Number of science subjects taken in the general education & 0.08 & .04 & $.03^{*}$ & .0005 \\
\hline
\end{tabular}
$* p<.05$. 
As shown in Table 2, each of the general education diploma average score, general education diploma mathematics subject score, general education diploma English language subject score, number of science subjects taken in the general education diploma, self-efficacy for learning and performance, and self-regulation associated positively with the critical thinking ability after controlling other variables. University readiness, rehearsal, and peer learning regulation associated negatively with the critical thinking ability after controlling for other variables. Also, females scored on average higher than males in the CCTST after controlling for other variables. Basic education students scored on average higher than non-basic education students in the CCTST after controlling other variables. On average, students having pure mathematics scored in the CCTST higher than those having applied mathematics. The regression analysis excluded intrinsic goal orientation, extrinsic goal orientation, control of learning beliefs, elaboration, organization, time and study environment, effort regulation, and helpseeking as having a statistically predictive value of the critical thinking ability.

In order to assess the unique contribution of the independent variables to the total variance of the dependent variable, a squared semi-partial correlation coefficient $\left(s r^{2}\right)$ was computed for each variable as presented in Table 2. Results revealed that the largest contributor to the total variance of the critical thinking ability scores was the English language subject score obtained by the student in the general education diploma. The least contributor to the total variance of the critical thinking ability scores was the number of science subjects taken in the general education diploma.

\section{DISCUSSION}

Overall, the results contribute to the limited research literature investigating predictors of critical thinking ability of university students (Ingle, 2007; Magno, 2010; Uzuntiryaki-Kondakçi \& Çapa-Aydin, 2013). These results allow researchers and educational practitioners to formulate a predictive model of critical thinking at university level based on cognitive and motivational factors as well as background and demographic factors. For example, as shown in the present study, male students coming from non-basic general education diploma schools with fewer science courses and poor performance in English language and mathematics could be asked upon entry to the university to enroll in foundation programs aimed at enhancing their cognitive skills to develop better critical thinking ability. Also, the present study showed that peer learning negatively predicted critical thinking ability after controlling for other predictor variables. This implies that peer learning, as a learning strategy, might not have been thoughtfully planned and implemented in the general education diploma schools. Research has shown that peer learning might have an adverse effect on critical thinking when peer interaction involves copying assignments rather than ensuring peers understand the information (Slavin, 1996; Van Meter \& Stevens, 2000; Williams \& Worth, 2001).

Although past research using the Watson-Glaser Critical Thinking Appraisal revealed contradictory results regarding gender differences in the ability to think critically (Ingle, 2007), the present study found that females outperformed males on the CCTST after controlling for other predictor variables. One possible explanation for the gender-based 
variation in the critical thinking ability could be that female students tended to be more motivated for learning than male students (Shekhar \& Devi, 2012). Another possible explanation could be that female students tended on average to outperform male students in the secondary school (Fortin, Orepoulos, \& Phipps, 2015).

With regard to future research, it would be useful to consider developing a taxonomy of cognitive and non-cognitive dimensions of university students to be used for improving the critical thinking ability. Also, future researchers might consider including other intrapersonal variables in the prediction model of the critical thinking ability of university students. Further, it would be useful to test the validity of the model using samples from other colleges and universities in the Sultanate of Oman.

Further, future research might explore the relevance of the recent additions to the debate about the nature and definition of critical thinking. For example, must critical thinking have discipline specific definitions as Moore (2011) suggests or are there specific transferrable skills that can be taught across disciplines as Davies (2013) and Faccione $(1990,2013)$ argue? While the current study was based on the latter, it is possible that the CCTST focuses on specific discipline skills related to medicine, nursing, engineering and education. If so, while the improvements in critical thinking skill attainment in those colleges may be valid, it is possible that other critical thinking skills may have been learned in other colleges but went untested in the present research study.

\section{CONCLUSION}

The purpose of this study was to investigate predictors of critical thinking ability among Sultan Qaboos University students. This was done through the development of a predictive model using demographic, background, and psycho-educational variables. In conclusion, the results revealed that the final full model included gender, type of general diploma education, type of general diploma math subject, number of general diploma science subjects taken, overall general diploma GPA, general diploma math subject score, general diploma English language subject score, college readiness, self-efficacy for learning and performance, peer learning, rehearsal, and metacognitive self-regulation as collectively statistically significant predictors of the critical thinking ability. It accounted for $8.7 \%$ of the variance in the critical thinking ability. The English language subject score obtained by the student in the general education diploma was the most robust predictor of the critical thinking ability. Thus, the results of the study illustrate the need for additional empirical investigation about predictors of the critical thinking. Also, the results highlight the need for educators at the secondary school level to fostering on what might facilitate the development of the critical thinking ability of the students.

Finally, although the findings of the current study provide the basis for designing support programs to help students develop their critical thinking ability, there are limitation to be considered when interpreting the findings. Specifically, the findings do not imply causal relationships despite the longitudinal nature of the data. Replicating the study using data drawn from different cohorts and universities might maximize the generalizability of the findings. 


\section{REFERENCES}

Alkharusi, H., Neisler, O., Al-Barwani, T., Clayton, D., Al-Sulaimani, H., Khan, M. A., Al-Yahmadi, H., \& Al-Kalbani, M. (2012). Psychometric properties of the Motivated Strategies for Learning Questionnaire for Sultan Qaboos University students. College Student Journal,46, 567-580.

Arslan, R., Gulveren, H., \& Aydin E. (2014). A research on critical thinking tendencies and factors that affect critical thinking of higher education students. International Journal of Business and Management,9 (5), 43-59.

Beyer, B. K. (1984). Improving thinking skills: Practical approaches. Phi Delta Kappan, $65,556-560$.

Cohen, J. (1988). Statistical Analysis for the Behavioral Sciences $\left(2^{\text {nd }}\right.$ ed.). Lawrence Erlbaum.

Davies, M. (2013). Critical thinking and the disciplines reconsidered. Higher Education Research \& Development. 32(4), 529-544.

Ennis, R.H. \& Millman, J. (1985). Cornell critical thinking test, level X. Pacific Grove, CA: Midwest Publications

Ennis, R. H., \& Weir, E. (1985). The Ennis-Weir critical thinking essay test. Pacific Grove, CA: Midwest Publications.

Facione, P. (1990). The California Critical Thinking Skills Test: Technical Report \#2Factors Predictive of CT Skills. ERIC Doc. No.: TM 015819.

Facione, P. (2000). The California Critical Thinking Skills Test (CCTST). Millbrae, CA: California Academic Press.

Facione, P. A. (2011). Critical thinking: What is it and why it counts. Retrieved from http://www.insightassessment.com/content/download/../what\&why2010.pdf

Facinoe, N. (2013). California Critical Thinking Skills Test (CCTST Test Manual). Millbrae, CA: California Academic Press.

Fortin, N., Orepoulos, P., \& Phipps, S. (2015). Leaving boys behind: Gender disparities in high academic achievement. Journal of Human Resources, 50 (1), 549-579. doi:10.3368/jhr.50.3.549

Gonzalez, G., Karoly, L., Constant, L., Salem, H., \& Gold, C. (2008). Facing human capital challenges of the $21^{\text {st }}$ century: Education and labor market initiatives in Lebanon, Oman, Qatar, and the United Arab Emirates. Santa Monica, CA: Rand.

Heppner, P. P., \& Petersen, C. H. (1982). The development and implications of a personal problem-solving inventory. Journal of Counseling Psychology, 29(1), 66-75. doi: 10.1037/0022-0167.29.1.66

Hohmann, J. W., \& Grillo, M. C. (2014). Using critical thinking rubrics to increase academic performance. Journal of College Reading and Learning, 45(1), 35-51. doi:10.1080/10790195.2014.949551 
Indah, R., \& Kusuma, A. (2016). Factors affecting the development of critical thinking of Indonesian learners of English language. IOSR Journal of Humanities and Social Science, 21 (6), 86-94. doi:10.9790/0837-2106088694

Ingle, C. O. (2007). Predictors of critical thinking ability among college students. Available from ProQuest Dissertations \& Theses Global. (304844391). Retrieved from http://search.proquest.com/docview/304844391 ?accountid=27575

Ip, W. Y., Lee, D. T., Lee, I. F., Chau, J. P., Wootton, Y. S., \& Chang, A. M. (2000). Disposition towards critical thinking: a study of Chinese undergraduate nursing students. Journal of Advanced Nursing, 32 (1), 84-90. doi:10.1046/j.1365-2648.2000.01417.x

Karagol, I., \& Bekmezci, S. (2015). Investigating academic achievements and critical thinking dispositions of teacher candidates. Journal of Education and Training Studies, 3(4), 86-92. doi:10.11114/jets.v3i4.834

Khalili, H., \& Zadeh, H. (2003). Investigation of reliability, validity and normality Persian version of the California Critical Thinking Skills Test; Form B (CCTST). Journal of Medical Education, 3 (1), 29 - 32.

Lai, E. R. (2011). Critical thinking: A literature review. Retrieved from http://www.pearsonassessments.com/research

Magno, C. (2010). The role of metacognitve skills in developing critical thinking. Metacognitive Learning, 5, 137 - 156. doi:10.1007/s11409-010-9054-4

Mahapoonyanont, N. (2012). The causal model of some factors affecting critical thinking abilities. Procedia - Social and Behavioral Sciences, 46, 146-150. doi:10.1016/j.sbspro.2012.05.084

Mayer, R., \& Goodchild, F. (1990). The critical thinker. New York: Wm. C. Brown.

Ministry of Education and the World Bank. (2012). Education in Oman: The drive for quality. Oman: Author.

Moore, T. J. (2011). Critical thinking and disciplinary thinking: a continuing debate. Higher Education Research \& Development, 30(3), 261-274. doi:10.1080/07294360.2010.501328

Neisler, O. (1999). The right to learn: A blueprint for school reform. Educational Policy, 13 (2), 318-328. doi:10.1177/0895904899132005

Neisler, O. (2000). How does teacher education need to change to meet the needs of America's schools at the start of the 21st century? Journal of Teacher Education, 51 (3), 248-255. doi: 10.1177/0022487100051003014

Norris, S. P., \& King, R. (1984). The design of a critical thinking test on appraising observations. Institute for Educational Research and Development, Memorial University of Newfoundland, S1. Johns, Newfoundland.

O'Hare, L., \& McGuinness, C. (2015). The validity of critical thinking tests for predicting degree performance: A longitudinal study. International Journal of Educational Research, 72, 162 - 172. doi: 10.1016/j.ijer.2015.06.004 
Paul, R., \& Elder, L. (2006). The miniature guide to critical thinking: Concepts and tools. Dillon Beach CA: The Foundation for Critical Thinking.

Phan, H. (2008). Multiple regression analysis of epistemological beliefs learning approaches and self-regulated learning. Electronic Journal of Research in Educational Psychology, 6 (1), 157 - 184.

Pintrich, P. R., Smith, D. A. F., Garcia, T., Mckeachie, W. (1993). Reliability and predictive validity of the motivated strategies for learning questionnaire (MSLQ). Educational and Psychological Measurement, 53, 801-813. doi: 10.1177/0013164493053003024

Shekhar, C., \& Devi, R. (2012). Achievement motivation across gender and different academic majors. Journal of Educational and Developmental Psychology, 2(2), 105109. doi: $10.5539 /$ jedp.v2n2p105

Slavin, R. E. (1996). Research on cooperative learning and achievement: What we know, what we need to know. Contemporary Educational Psychology, 21, 43 - 69. doi:10.1006/ceps.1996.0004

Sultan Qaboos University. (2017). Graduate Attribute. Retrieved http://www.squ.edu.om/About/About-SQU/SQU-Graduate-Attributes.

Tabachnick, B. G., \& Fidell, L. S. (2001). Using multivariate statistics (4th ed.). Needham Heights, MA: Allyn \& Bacon.

Times News Service. (2014, April 23). Oman's population passes landmark figure. Times of Oman. Retrieved http://www.timesofoman.com/News/32830/ArticleOman\%E2\% 80\%99s-population-passes-landmark-figure.

Tümkaya S., Aybek, B., \& Aldağ, H. (2009). An investigation of university students' critical thinking disposition and perceived problem solving skills. Eurasian Journal of Educational Research, 36, 57-74.

Uzuntiryaki-Kondakçi, E., \& Çapa-Aydin, Y. (2013). Predicting critical thinking skills of university students through metacognitive self-regulation skills and chemistry selfefficacy. Educational Sciences: Theory and Practice, 13 (1), 666 - 670.

Van Meter, P., \& Stevens, R. J. (2000). The role of theory in the study of peer collaboration. Journal of Experimental Education, 69 (1), 113 - 127. doi: $10.1080 / 00220970009600652$

Wade, C., \& Tavris C. (1987). Psychology. New York: Harper \& Row.

Watson, G., \& Glaser, E. M. (1980). Watson-Glaser Critical Thinking Appraisal. San Antonio, TX: Psychological Corp.

Williams, R. L., \& Worth, S. L. (2001). The relationship of critical thinking to success in college. Inquiry: Critical Thinking Across the Disciplines, 21 (1), 5 - 16. doi:10.5840/inquiryctnews200121123 